\title{
Possible Applications of Soil Remediation Technologies in Latvia
}

\author{
Juris Burlakovs ${ }^{1}$, Magnuss Vircavs ${ }^{2},{ }^{1-2}$ Faculty of Geography and Earth Sciences, University of Latvia
}

\begin{abstract}
Increasing public concern about deleterious effects of contamination on the environment and human health has led to legislative actions aimed at controlling and regulating the emission of potential contaminants into the environment, but there is still a plethora of territories historically contaminated with different contaminants within the territory of Latvia.

The purpose of the present study is to give an overview of the formerly and presently contaminated areas and give some recommendations for remediation. 242 first category contaminated territories (the contamination exceeds the acceptable normative 10 times or more) are mentioned in the National Register of Contaminated Territories, a lot of them are known as contaminated with hazardous contaminants such as heavy metals, oil products, organic compounds and other contaminants in different amounts and concentrations. An overview of soil contamination in Latvia is provided, the planned and recommended research, as well as the planned remediation in pilot case studies, are described, giving a review of the historical contamination situation and of applications of the planned remediation technologies.
\end{abstract}

Keywords - Soil remediation, historical contamination, stabilization / solidification technology, brownfields

\section{INTRODUCTION}

Contamination of ecosystems is an integral part of the modern society development. All over the world, contaminated sites cause a large environmental problem. The 1960s can be supposed as a keystone in environmental thinking - to comprise such development that has to be based on the coexistence of the environment and industry. Throughout Europe and the USA, contaminated land and hazardous sites became generally recognized in the 1970s, but a decade later most industrial nations started efforts to systemize the decision-making process for the evaluation and treatment of contaminated land [18]. Nowadays there are no harmonized definitions of contaminated sites, land and soil. They are frequently used as synonyms, but they do not really have the same meaning. However, the term 'contaminated land or site' is most often used to describe the land or site where there is a suspicion that the contamination could be harmful to humans, water, buildings or ecosystems. Considering information on a variety of contaminated sites, the concept of potentially contaminated sites was proposed. They differ with information completeness on the contamination character [15].

Development of soil and groundwater remediation technologies is a matter of great importance to eliminate the historically and currently contaminated sites, because contamination deteriorates the environmental quality, the possibilities of site operation, and the use of land at its full value. Contamination causes loss of land as a resource, as well as loss of property. The aim of remediation activities is to transform unusable contaminated estates into available use and conserve land resources, to improve environmental conditions in the contaminated site and around it, as well as to reduce the risk to humans and the environment. Remediation means actions taken to cleanup, mitigate, correct, abate, minimize, eliminate, control and contain or prevent release of a contaminant into the environment in order to protect human health and the environment, including actions to investigate, study and assess any actual or suspected release [26].

The general problem is how much remediation should be undertaken considering a large number of the contaminated sites all over the world, e.g. according to the European Commission, EU counts $\sim$ 3-5 million potentially contaminated sites and 500000 known contaminated sites. The latter need remediation activities [22]. Some authors [2] emphasize the following three remediation decisions. First, a background analysis must determine the extent of contamination and remediation alternatives. Second, the remedy must be selected on the basis of a number of criteria, including those related to technical, environmental, and financial or economic factors. Third, a decision must be made about when to stop the remediation activities.

In Latvia the assessment and evaluation of contaminated and potentially contaminated sites began in the 1980s. The National Register of Contaminated Territories (NRCT) of Latvia was established in 2002 [27]. The NRCT covers the territories that are contaminated with various materials, inorganic and organic, including hazardous and nonhazardous substances. In NRCT, the sites are divided into three categories, using the following criteria. The first category includes the sites, where contamination exceeds the acceptable normative 10 times or more. The use of these areas for new construction or land use purposes is possible only after the territory remediation actions. The first category applies to 242 contaminated sites according to the situation on 30 June 2011. The second category means that the territory is contaminated up to 10 times more than the legislative norms. Contamination can negatively impact ecosystems and the area needs additional researches to obtain the necessary data on the contamination character. This category comprises the potentially contaminated sites. At present, there are 2655 sites of the second category in Latvia. In the contaminated sites of the third category, the concentrations of the polluted substances do not exceed the acceptable norms, and contamination cannot impact the quality of the environment. 
The third category of 669 contaminated areas comprises mostly the territories that are excluded from the lists of the first and second categories after research and / or remediation activities.

The purpose of the present study is to summarize the information on contaminated territories in Latvia and to give recommendations for possible remediation applications. The focus is mainly put on the first category - the sites contaminated with heavy metals, e.g. $\mathrm{Cr}, \mathrm{Pb}, \mathrm{Cd}, \mathrm{Hg}, \mathrm{Ni}$, and $\mathrm{Zn}$, as well as some other sites contaminated with oil products. In order to distinguish the areas, the contaminated sites of the first category list were analyzed. In more than 50 sites, contamination with heavy metals was detected, and about 200 areas have high contamination with oil products. Therefore, many of these sites may be included in the list for future remediation actions.

The paper describes some legislative aspects, a scientific and technological overview of soil contamination remediation techniques, in general, and, mostly for heavy metal contamination, treatment and possible applications in Latvia.

\section{LEGISLATION}

The Law "On Pollution" (came into force on 1 July 2001) defines the procedures in the sphere of contamination [10]. The purpose of the Law (Section 2) is to prevent or reduce harm caused to human health, property or the environment due to pollution and to eliminate the consequences of harm caused. A local government in co-operation with the relevant Regional Environmental Board of State Environmental Service has an obligation to ascertain and initially assess polluted and potentially polluted sites in a relevant administrative territory (Section 33). The Ministry of Defence has to ascertain and initially assess polluted territories in its possession and notify the relevant local government and regional environmental board thereof (Section 34).

Methods and procedures for ascertaining polluted and potentially polluted sites, as well as the procedures for financing, conditions for data collection and utilisation are regulated by the Cabinet of Ministers' Regulations No. 483 adopted on November 202001 "Inventory and Registration of Contaminated and Potentially Contaminated Areas" [17].

The Latvian Environmental, Geological and Meteorological Center (the supervised institution of the Ministry of Environmental Protection and Regional Development, MEPRD) has an obligation to maintain all collected and processed information about contaminated sites.

Special attention is paid to the territories of historical military unexploded ammunition and explosive sites that has resulted from warfare during World War II. Therefore, MEPRD, in cooperation with the German Ministry of the Environment and the Latvian Ministry of Defence, prepared the Cabinet of Ministers' draft regulations "On Legislative Regulations for Remediation of Contaminated Sites with Historical Military Unexploded Ammunition and Explosive Sites" in 2005. This legislative act is anticipated to govern the procedure of licensed companies to license enterprises capable to investigate and remediate unexploded ordnance and explosive objects in contaminated sites [7]. At present, the Regulations have not yet been approved by the government.

\section{Classification Of Remediation TeChNOlogies AND CONTAMINATED SITES}

Remediation technologies are divided into various groups, using the following criteria: a) type of application (in-situ and ex-situ remediation techniques, as well as on site and off site technologies); b) technologies acting on the contaminant (heavy metals, inorganic and organic substances, e.g. pesticides, and others); c) technologies based on the used processes (biological, physical separation, physical, chemical, and thermal), and non-saturated and saturated zone technologies [16]. Contaminated sites with heavy metals, oil products and other contaminating substances and materials can be found in current industrial areas, as well as in abandoned industrial territories, illegal dumping sites, harbors, agricultural and residential areas with historical contamination, road sides and elsewhere. Contaminated sites from the list of national importance, generally, can be grouped in sub-categories, as by their former or present economic use. Contaminated sites in Latvia can be divided as follows in the next paragraph.

The first sub-category, which can be outlined in a distinct way, contains the former dump sites of mixed waste. In the former USSR, various kind of municipal, residential and construction waste, as well as hazardous substances and materials, were often dumped in these dump sites. Table 1 shows the main contaminated sites of the first category, the type of contamination, as well as probable recommendations for remediation actions of some of the noted sites.

Another very important group is former military territories, which have remained after the collapse of the former USSR. After World War II, more than 1000 units of the Soviet Army forces were located in about 600 military sites that covered $10 \%$ of Latvia's territory. The largest firing-grounds were Zvārde, Liepaja Navy port (Karaosta), Rudbārži missile base, and Lielvārde airfield. Site pre-investigations and remediation have been carried out in some of the former military territories, e.g. Rumbula airfield, where soil and groundwater were contaminated with oil products. A total area of 6 ha was contaminated with oil products, and during 2000-2002 1730 $\mathrm{m}^{3}$ of contaminated groundwater $\left(\sim 80 \mathrm{~m}^{3}\right.$ of pure oil product) were pumped out [27]. Contamination with heavy metals, toxic organic substances and also with oil products was determined in about 11 military territories. In spite of the remaining historical contamination, some of these territories have been readjusted for the use with another purpose, e.g. the area of the Riga Freeport.

Areas of industrial contamination (brownfields) - a lot of raw materials, including heavy metals, various heavy metals compounds, inorganic and organic substances, have been used in these territories. Industrial development simultaneously caused site contamination that in many cases is set as historical contamination. The former military industrial areas could also be included in this sub-category, but in the frame of 
the current paper, these categories are separated for better understanding.

Especially hazardous sites must be counted separately, e.g. the liquid toxic substances dump site in Jelgava (mostly groundwater contamination), the biomedical and chemical industry dump site (Olaine), former treatment facilities of Riga and similar sites.

General group of contaminated areas comprises exwarehouses, former and existent fields of iron-scrap, well-

TABLE I

LIST OF MAIN CONTAMINATED SITES OF THE FIRST CATEGORY, TYPE OF CONTAMINATION AND RECOMMENDATIONS FOR PROBABLE REMEDIATION ACTIONS [27]

\begin{tabular}{|c|c|c|c|}
\hline No & Location, name & Type of contamination & $\begin{array}{l}\text { Recommendations for probable remediation } \\
\text { actions }\end{array}$ \\
\hline 1. & JSC Lokomotīve, Daugavpils, industrial area & $\mathrm{HM}^{1}, \mathrm{OP}^{2}$ & Environmental contamination assessment \\
\hline 2. & Liquid toxic substances dump, Jelgava & $\mathrm{HM}$, elements in anionic form, OP & Groundwater treatment methods \\
\hline 3. & Zvārde tank polygon, former military area & $\mathrm{OP}, \mathrm{HM}$ & Phytoremediation \\
\hline 4. & Liepaja Port Channel & HM & Stabilization/solidification \\
\hline 5. & Former Pesticides Warehouse, Viḷāni & $\mathrm{DDT}^{3}, \mathrm{HM}$ & Environmental contamination assessment \\
\hline 6. & $\begin{array}{l}\text { "BIOLAR" dump of toxic substances, } \\
\text { Olaine, }\end{array}$ & Toxic hazardous substances, HM & Groundwater treatment methods \\
\hline 7. & Olaine dump site & $\mathrm{HM}$ & Risk assessment, monitoring, re-cultivation \\
\hline 8. & Mārupe Landfill & $\mathrm{COD}^{4}, \mathrm{~N}, \mathrm{P}$ & Risk assessment, monitoring, re-cultivation \\
\hline 9. & Priedaine dump site & COD, ammonia, OP, HM, N & $\begin{array}{l}\text { Risk assessment, monitoring, re-cultivation, reactive } \\
\text { walls }\end{array}$ \\
\hline 10. & $\begin{array}{l}\text { Bangas, former Soviet Army missile base, } \\
\text { former military area }\end{array}$ & $\mathrm{OP}, \mathrm{HM}$ & $\begin{array}{l}\text { Risk assessment, stabilization / solidification, } \\
\text { phytoremediation }\end{array}$ \\
\hline 11. & Ventspils fishing port, fuel base & $\mathrm{OP}, \mathrm{HM}(\mathrm{Zn}, \mathrm{Cu}, \mathrm{Pb})$ & Environmental contamination assessment \\
\hline 12. & Ķilupe Landfill, Ogresgals & $\mathrm{COD}$, elements in anionic form, $\mathrm{N}$ & $\begin{array}{l}\text { Risk assessment, monitoring, re-cultivation, reactive } \\
\text { walls }\end{array}$ \\
\hline 13. & Getliņi Landfill, Riga & Elements in anionic form, $\mathrm{N}, \mathrm{COD}$ & $\begin{array}{l}\text { Risk assessment, monitoring, reactive walls, soil } \\
\text { flushing }\end{array}$ \\
\hline 14. & $\begin{array}{l}\text { JSC Bolderāja Former Sewage Treatment } \\
\text { System, Riga Port }\end{array}$ & COD, surfactants, Fe, sulphates, N, OP, HM & Stabilization/solidification \\
\hline 15. & $\begin{array}{l}\text { Lacon Ltd., former Soviet Army fuel base, } \\
\text { Riga Port }\end{array}$ & $\mathrm{OP}, \mathrm{HM}(\mathrm{Pb})$ & Stabilization/solidification \\
\hline 16. & $\begin{array}{l}\text { Bolderāja ship repair yard, Riga Port, } \\
\text { brownfield }\end{array}$ & $\begin{array}{l}\text { OP, COD, alcohols, phenols, surfactants, } \mathrm{N} \text {, } \\
\mathrm{HM}(\mathrm{Pb}, \mathrm{Cd}, \mathrm{Cu})\end{array}$ & Stabilization/solidification \\
\hline 17. & Mekora, Ltd., Former 145. Military Factory, & $\mathrm{OP}, \mathrm{COD}, \mathrm{HM}(\mathrm{Ni}, \mathrm{Zn}, \mathrm{Cu}, \mathrm{Pb})$ & Environmental contamination assessment \\
\hline 18. & Kleisti dump site, Riga & $\begin{array}{l}\mathrm{HM}(\mathrm{Zn}, \mathrm{Pb}, \mathrm{Cr}), \mathrm{COD}, \mathrm{N} \text {, elements in } \\
\text { anionic form }\end{array}$ & $\begin{array}{l}\text { Risk assessment, monitoring, recultivation, reactive } \\
\text { walls, soil flushing }\end{array}$ \\
\hline 19. & KRS Ltd., Riga Port industrial area & $\begin{array}{l}\text { Adhesive waste from paints, varnishes, inks, } \\
\text { OP, HM, Hg }\end{array}$ & $\begin{array}{l}\text { Environmental contamination assessment, } \\
\text { groundwater treatment methods }\end{array}$ \\
\hline 20. & $\begin{array}{l}\text { Freja Ltd., former Soviet Army Territory, } \\
\text { Riga Port }\end{array}$ & $\mathrm{HM}, \mathrm{OP}$ & $\begin{array}{l}\text { Risk assessment, monitoring, } \\
\text { stabilization/solidification }\end{array}$ \\
\hline 21. & $\begin{array}{l}\text { Russo-Balt Ltd., Riga former military } \\
\text { factory }\end{array}$ & $\mathrm{HM}(\mathrm{Pb}, \mathrm{Zn}, \mathrm{Cd}), \mathrm{OP}$ & Environmental contamination assessment \\
\hline 22. & JSC Latvijas Krāsmetāli, Riga, brownfield & $\mathrm{HM}, \mathrm{OP}$ & Environmental contamination assessment \\
\hline 23. & Former "Alfa" area, Riga, brownfield & $\begin{array}{l}\text { Trichlorethylene, COD, SAS, OP, alcohols, } \\
\text { phenols, HM }\end{array}$ & $\begin{array}{l}\text { Risk assessment, stabilization/solidification, } \\
\text { phytoremediation }\end{array}$ \\
\hline 24. & Deglava Street dump site & $\mathrm{COD}, \mathrm{N}, \mathrm{V}$, elements in anionic form & Risk assessment, monitoring, re-cultivation \\
\hline 25. & "Former Alfa Area 2, Riga, brownfield & Ammonia, acids, HM & $\begin{array}{l}\text { Risk assessment, stabilization/solidification, } \\
\text { phytoremediation }\end{array}$ \\
\hline 26. & Latvijas Nafta, Riga, brownfield & $\mathrm{COD}, \mathrm{OP}, \mathrm{HM}(\mathrm{Zn}, \mathrm{Pb})$ & Environmental contamination assessment \\
\hline 27. & Bieķengrāvis, former hazardous waste dump & $\mathrm{COD}, \mathrm{OP}, \mathrm{N}, \mathrm{HM}(\mathrm{Cu})$ & Environmental contamination assessment, \\
\hline 28. & Viva Color Ltd., Riga, brownfield & Phenols, N, HM (Pb, Zn) & Risk assessment, stabilization/solidification, \\
\hline
\end{tabular}




\begin{tabular}{|c|c|c|c|}
\hline & & & phytoremediation \\
\hline 29. & Eko Osta, Riga Port, former Soviet fuel base & $\mathrm{OP}, \mathrm{HM}$ & $\begin{array}{l}\text { Risk assessment, stabilization/solidification, } \\
\text { phytoremediation }\end{array}$ \\
\hline 30. & $\begin{array}{l}\text { Riga Gardening Pesticide Warehouses } \\
\text { (former) }\end{array}$ & $\mathrm{OP}, \mathrm{HM}$ & $\begin{array}{l}\text { Risk assessment, stabilization/solidification, } \\
\text { phytoremediation }\end{array}$ \\
\hline 31. & $\begin{array}{l}\text { "Energoautomātika" former industrial area, } \\
\text { Riga }\end{array}$ & $\mathrm{Pb}, \mathrm{As}$ & Environmental contamination assessment \\
\hline 32. & Vega Stividors, Riga Port, industrial area & $\mathrm{HM}$, As & Stabilization/solidification, phytoremediation \\
\hline 33. & BLB, Riga Port, industrial area & HM, OP, HM (As) & Stabilization/solidification, phytoremediation \\
\hline 34. & Magnāts Ltd., Riga Port, industrial area & $\mathrm{OP}, \mathrm{HM}(\mathrm{Pb})$ & Stabilization/solidification, phytoremediation \\
\hline 35. & $\begin{array}{l}\text { Grand Ltd. former light bulb factory, } \\
\text { brownfield }\end{array}$ & $\mathrm{OP}, \mathrm{HM}(\mathrm{Pb}, \mathrm{Cu})$ & Environmental contamination assessment \\
\hline 36. & JSC Starts Riga, industrial area & COD, HM (Pb) & Environmental contamination assessment \\
\hline 37. & SJSC Latvenergo TEC-1, Riga, brownfield & $\mathrm{OP}$, elements in anionic form, ammonia, $\mathrm{HM}$ & Environmental contamination assessment \\
\hline 38. & Jēkabpils terminal & $\mathrm{OP}$ & Groundwater treatment methods \\
\hline 39. & Former mordant site, Ancene & Amines, $\mathrm{HM}(\mathrm{Cu}, \mathrm{Zn})$ & Environmental contamination assessment \\
\hline 40. & $\begin{array}{l}\text { Black oil warehouse, Višksi professional } \\
\text { secondary school }\end{array}$ & OP & Groundwater treatment methods \\
\hline 41. & $\begin{array}{l}\text { Warehouse of forestry, Otaņķi, "Oškalni", } \\
\text { Nīca area }\end{array}$ & DDT & $\begin{array}{l}\text { Environmental contamination assessment, } \\
\text { electrokinetic, stabilization/solidification }\end{array}$ \\
\hline 42. & Oil product base "Evija", Liepaja, 2 sites & $\mathrm{OP}$ & Groundwater treatment methods \\
\hline 43. & $\begin{array}{l}\text { Former reinforced concrete factory, } \\
\text { Aizkraukle }\end{array}$ & OP & Groundwater treatment methods \\
\hline 44. & Alūksne military site & OP & Groundwater treatment methods \\
\hline 45. & $\begin{array}{l}\text { Inčukalns Goudron Ponds - Southern and } \\
\text { Eastern ( } 2 \text { sites) }\end{array}$ & $\mathrm{OP}$, elements in anionic form, COD & Groundwater treatment methods \\
\hline 46. & Riga Airport former oil base, Mārupe County & OP & Groundwater treatment methods \\
\hline 47. & Rumbula, former military air base (6 sites) & OP & Groundwater treatment methods \\
\hline 48. & Tilts Baltija, former military area & OP, jet fuel & Groundwater treatment methods \\
\hline 49. & Spilve airport, former oil base & $\mathrm{OP}$ & Groundwater treatment methods \\
\hline 50. & "Rigas Tilti", former military area & OP, gasoline & Groundwater treatment methods \\
\hline 51. & $\begin{array}{l}\text { "Latvijas Dzelzcel̦š" locomotive equipment } \\
\text { point ( } 2 \text { sites) }\end{array}$ & OP & Groundwater treatment methods \\
\hline 52. & Latvenergo gas station, Riga & OP & Groundwater treatment methods \\
\hline 53. & Latvija Statoil gas station, Maskavas str. 349 & $\mathrm{OP}$ & Excavation \\
\hline 54. & VEF former oil base & OP, trichlorethylene & Groundwater treatment methods \\
\hline 55. & Vudisona Terminal, Riga Port (2 sites) & $\mathrm{OP}$ & Groundwater treatment methods \\
\hline 56. & VL Bunkering, Riga Port & $\mathrm{OP}$ & Groundwater treatment methods \\
\hline 57. & Oil and grease plant & $\mathrm{OP}$ & Groundwater treatment methods \\
\hline 58. & Man Tess, Ltd. & $\mathrm{OP}$ & Groundwater treatment methods \\
\hline 59. & $\begin{array}{l}\text { Gas Stations ( } 2 \text { sites) near Sarkandaugava } \\
\text { Ditch }\end{array}$ & $\mathrm{OP}$ & Groundwater treatment methods \\
\hline 60. & Valmiera Glass Fiber & OP & Groundwater treatment methods \\
\hline 61. & $\begin{array}{l}\text { Hazardous Waste Dump Site in Zvāre quarry } \\
\text { (Tukums area) }\end{array}$ & OP & Groundwater treatment methods \\
\hline 62. & Former tank gas station, Ventspils & $\mathrm{OP}$ & Groundwater treatment methods \\
\hline 63. & Venstpils Port, (8 sites) & OP & Groundwater treatment methods \\
\hline
\end{tabular}

1 - heavy metals and their compounds

2 - oil products

${ }^{3}$ - dichlorodiphenyltrichloroethane, 1,1,1-trichloro-2,2-di(4-chlorophenyl)ethane

${ }^{4}$ - contamination with organic substances, creating a high level of chemical oxygen demand

At present, many former industrial territories have become brownfields. These sites are researched by one or several municipalities, and afterwards they inform the relevant regional environmental board and submit it to the list. 


\section{APPLICATIONS}

In the middle of the 1990s the European Union framework cooperation for remediation of historically contaminated sites commenced in Latvia.

The following remediation technologies are or can be applied in Latvia: 1) stabilization/solidification (S/S); 2) soil flushing; 3) electrokinetic treatment; 4) phytoremediation and 5) bioremediation. The applicability of remediation technology is dependent on the site-specific conditions, the type of contaminants and other factors.

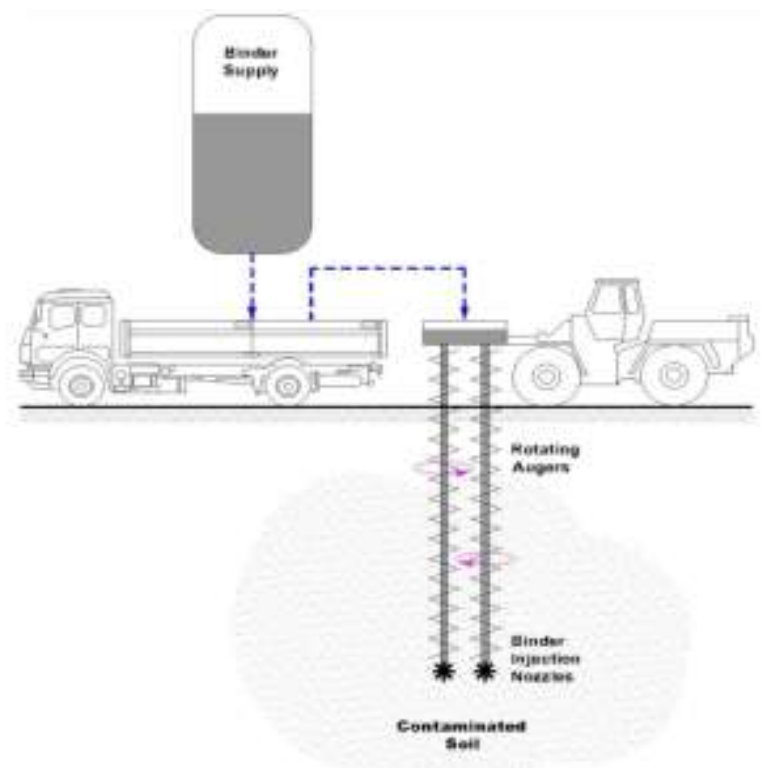

Fig. 1. Stabilization/solidification technology for remediation of various contaminants - heavy metals, oil products, PCB's, etc.

Pilot remediation studies were done in Riga and Liepaja ports where economic development is still active. The noted sites are included in NRCT, and they are the most contaminated areas with heavy metals and oil products. The studies carried out showed that heavy metal concentrations in the soil and groundwater were so high that the need for remediation should be a priority. The third most polluted area is Liepaja Military Port (Karosta). In mid-1990s the assessment of sediment quality in the Liepaja Military Port was carried out [28]. The obtained results show that sediments are mostly polluted with $\mathrm{Cd}, \mathrm{Cu}$, $\mathrm{Pb}, \mathrm{Hg}$ and $\mathrm{Zn}$. The geoaccumulation and pollution load indexes were used in order to compare the contamination levels in the Liepaja and Riga harbours [23]. The geochemical index $\left(\mathrm{I}_{\text {geo }}\right)$ [14] and the pollution load index (PLI) [19] are the main characteristics of sediment quality - the higher the values of $I_{\text {geo }}$ and PLI, the more contaminated are the sediments. The highest $\mathrm{I}_{\text {geo }}$ values were obtained for $\mathrm{Cd}\left(\mathrm{I}_{\text {geo }}=4.3\right)$ and $\mathrm{Pb}\left(\mathrm{I}_{\text {geo }}=4.6\right)$ in Liepaja Military Port and for Cd $\left(\mathrm{I}_{\text {geo }} 4.0\right)$ in the Riga Port. Considering geochemical index classification [14], variation of geoaccumulation indexes of $\mathrm{Cd}$ and $\mathrm{Pb}$ notifies their contamination character from unpolluted to strongly polluted or even to extremely polluted. $\mathrm{Cu}, \mathrm{Hg}$ and $\mathrm{Zn}$ pollution was stated as moderately polluted to strongly polluted. The maximum PLI values were observed for the sediment contamination of Liepaja Military Port (PLI - 5.0) and Riga harbor (PLI - 4.5). The uncontaminated state or background level of sediments was observed for $\mathrm{Ni}$ and $\mathrm{Cr}$ whose $\mathrm{I}_{\text {geo }}<0$. The wide range of $\mathrm{I}_{\text {geo }}$ of $\mathrm{Ni}$ and $\mathrm{Cr}$ characterizes their background level. The calculated $\mathrm{I}_{\text {geo }}$ and PLI show that sediments of Liepaja Military Port are the most polluted territories with $\mathrm{Cd}, \mathrm{Cu}, \mathrm{Pb}, \mathrm{Hg}$ and $\mathrm{Zn}$, comparably to the Riga Port sediments [28]. The carried out sediment quality assessment have led to the decision that the sediments need remediation after the technical economic evaluation in 2010. The pre-research in the Liepaja Military Port has shown that the high groundwater level is the disturbing factor for the application of excavation, as well as other ex situ technologies.

Therefore, considering the geological and economical obstacles, application of S/S technology (Fig. 1) is the most acceptable in this case. The remediation of the Liepaja harbour sediments after dredging out of the water body will be done using the S/S technology.

The selection of $\mathrm{S} / \mathrm{S}$ technology is a complex problem and the aim of $\mathrm{S} / \mathrm{S}$ is to reduce mobility of toxic compounds.

Successful results of S/S process could be achieved considering the type of solidified hazardous substances, their properties and the selected inorganic or organic binders. The possible binders used in S/S technology include: fluid fly ash, classic fly ash and cement as an additive, as well as some others. Cement, however, is the most common and the most often used binder $[8 ; 12 ; 24]$. The effectiveness of the applied $\mathrm{S} / \mathrm{S}$ technology is assessed by leaching tests that are based on extraction to define the possibility of the solidified mass to release contaminants into the environment [9]. The compressive strength characterizes how the solidified mass ensures its safe disposal [4]. The S/S technology is an indispensable tool in waste management, remediation and port redevelopment [25].

The in-situ technologies of separation/concentration include soil flushing and electrokinetic treatment.

Soil flushing is based on leaching with water, acids or other flushing solvents. The choice of washing solution has to address the contaminant presented in the soil and the possible environmental side effects. The contaminated fluid is collected and pumped to the surface where it can be re-circulated, removed, or treated or re-injected. The technology can be combined with physical barriers to avoid deep percolation. The technique can be used for in-situ treatment of soils contaminated with organics, metals and radionuclides.

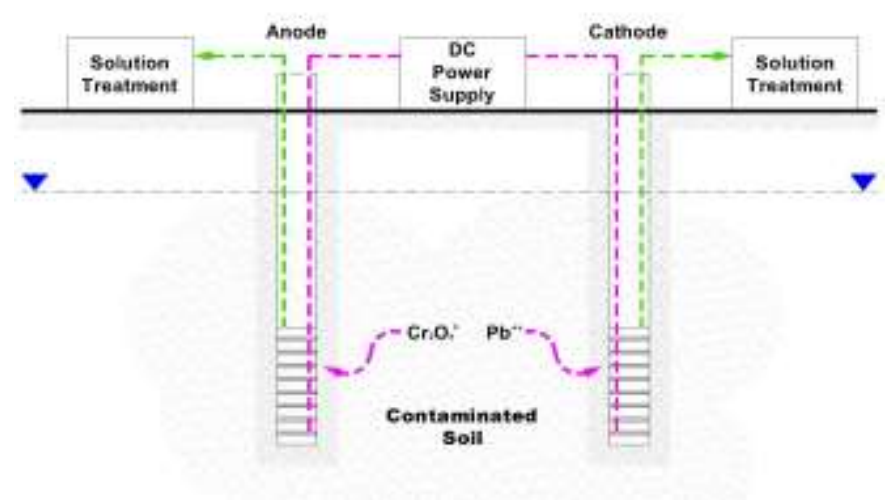

Fig. 2. Electrokinetic technology for heavy metal contamination remediation. 
Electrokinetic technology can be applied in wide areas, where there are no economic activities at the moment. Such places are former industrial and military firing-grounds, left after the collapse of the USSR. Electrokinetics is a quiet expensive technology. Electrokinetic technology (Fig. 2) is applicable to water soluble contaminants at sites with homogeneous soils that are fine-grained and exhibit both high permeability and high moisture contents. The technology is the most efficient when salinity and cation exchange capacity are low [3]. Electrokinetic technology has the following advantages: 1) may be able to treat soils not accessible for excavation; 2) potentially effective in both the saturated and unsaturated zone; 3) applicable in soils of low hydraulic conductivity, particularly with high clay content; 4) can treat both organic and inorganic contaminants. Limitations of the applicability of electrokinetic technology include the successive aspects: 1) contaminant solubility and the desorption of contaminants from the soil matrix may limit the success of the technology; 2) the process may not be efficient when the target ion concentration is low and the non-target ion concentration (background) is high; 3 ) the technology requires the presence of conducting pore fluid to mobilize contaminants; 4) heterogeneous or anomalies found at sites, such as submerged foundations, rubble, large quantities of iron or iron oxides, and large rocks or gravels that may reduce removal efficiencies [3].

Phytoremediation is a relatively new approach to removing contaminants from the environment. It may be defined as the use of plants to remove, destroy or sequester hazardous substances from the environment. Unfortunately, even plants, that are relatively tolerant of various environmental contaminants, often remain small in number and size in the presence of a contaminant [6]. Phytoextraction is very dependent on plant and soil factors, such as soil suitability for plant growth, depth of the contamination, depth of the plant root system, level of contamination, and urgency in cleaning up. Furthermore, there is need for a full understanding of the physiology, biochemistry, uptake etc., of the plants employed [5].The climatic conditions and bioavailability of metals must be taken into consideration using phytoremediation. The plants will have to be isolated from wildlife and agricultural lands. Once contaminated, the plants will have to be disposed of in an appropriate fashion. Some techniques include drying, incineration, gasification, pyrolysis, acid extractions, anaerobic digestion, extract of the oil, chlorophyll fibres from the plants or disposal of plants [1]. Phytoremediation will be the most applicable to shallow soils with low levels of contamination $(2.5-100 \mathrm{mg} / \mathrm{kg})$. In comparison with other remediation technologies, phytoremediation is a permanent technology. More research is needed to enhance the extraction of the metals by the plants through genetic breeding or other technologies and how to correlate bioavailability with metal uptake. Crop plants that grow fast may be viable for phytoremediation [13]. In spite of the slow process of phytoremediation that is limited by specific metal hyperaccumulator species and some other factors, phytoremediation mitigates environmental problems without the need to excavate the contaminated soil. It has been reported [19] that more than 750 terrestrial and aquatic plants have the potential value for phytoremediation. They are used to reduce a wide spectra of heavy metal concentrations in contaminated land and groundwater, for example, $\mathrm{Ni}, \mathrm{Cu}, \mathrm{Cd}$, $\mathrm{Cr}, \mathrm{Hg}, \mathrm{As}, \mathrm{Ag}, \mathrm{Se}, \mathrm{Zn}$. Results of several authors [20] indicate the potential for using some species of plants to treat $\mathrm{Hg}$ contaminated soil through stabilization, rather than extraction. However, phytoremediation has not been done in contaminated industrial sites in Latvia, but this approach should be used in further decontamination works, where the concentration of metals is not so high.

Biological technologies for remediation take advantage of the pathways developed by microorganisms to protect themselves from oil products and metals. Common protection mechanisms include oxidation/reduction, sorption and methylation. Biotechnologies that incorporate these mechanisms are in an advanced state of development for the remediation of organic compounds, but experience is limited for inorganic contaminants. Such processes as bioleaching, biosorption, biovolatilization, and biological oxidation and reduction may provide in situ treatments without the use of environmentally aggressive chemicals [11]. Techniques for the extraction of oil products and heavy metals by microbiological means are rather limited at this time. The main technologies include bioleaching and oxidation/reduction reactions. At present, biological treatment technologies are in development stage and will be experimentally tested in some brownfield areas in the near future. Microorganisms are also known to oxidize and reduce heavy metals, e.g. $\mathrm{Hg}$ and $\mathrm{Cd}$ can be oxidized, while As and Fe can be reduced by microorganisms, but $\mathrm{Cr}$ (VI) can be reduced to $\mathrm{Cr}$ (III) that is less mobile and toxic. Bacteria, such as Bacillus subtilis and sulphate reducing bacteria in the presence of sulphur can perform this reaction. Another process (called mercrobes) has been developed and tested in Germany at heavy metal concentrations greater than $100 \mathrm{ppm}$. Since the mobility is influenced by its oxidation state, these reactions can affect the contaminant mobility [13].

Reactive walls, isolation and containment approaches are used in order to stop the contaminating groundwater flow in combination with other remediational technologies. The advantages of this technique are that it is in situ, a wide variety of contaminants can be treated and flow control can be used. Further research is required in the areas of matching the contaminant with the media in the barrier, optimization of the flow and retention time through the barrier, and technologies of regenerating the media [13].

Inčukalns Southern and Northern goudron ponds are historical contaminated sites located $30-35 \mathrm{~km}$ from Riga. During 1950-1980 goudron was waste generated as the result of medical and perfumery oil production. Disregarding environmental protection measures, goudron and other chemical waste was dumped in a sandy pit in a foresed area. In 1986 the dump site was closed. Considering permeable and percolation sandy layers, contamination reached groundwater and artesian waters in the depth of $70-90 \mathrm{~m}$ by infiltration. In 2010 a remediation project of the Inčukalns goudron ponds 
began, the main task of which is to prevent contamination of the territories alongside with goudron ponds. Project implementation will include treatment with lime and replacement, excavation and disposal to landfill (with or without treatment) and un-engineered capping, as well as pumping out the contaminated waters, then treating and injecting it back into the subterranean (Fig. 3) in order to stop mobility of the contaminated plume. Otherwise, the contaminated plume, together with the groundwater flow, will reach the river Gauja horizon. Strong precautions will be taken during excavation and neutralization works in respect to air emissions, behaviour of tar and its ingredients in the soil and groundwater.

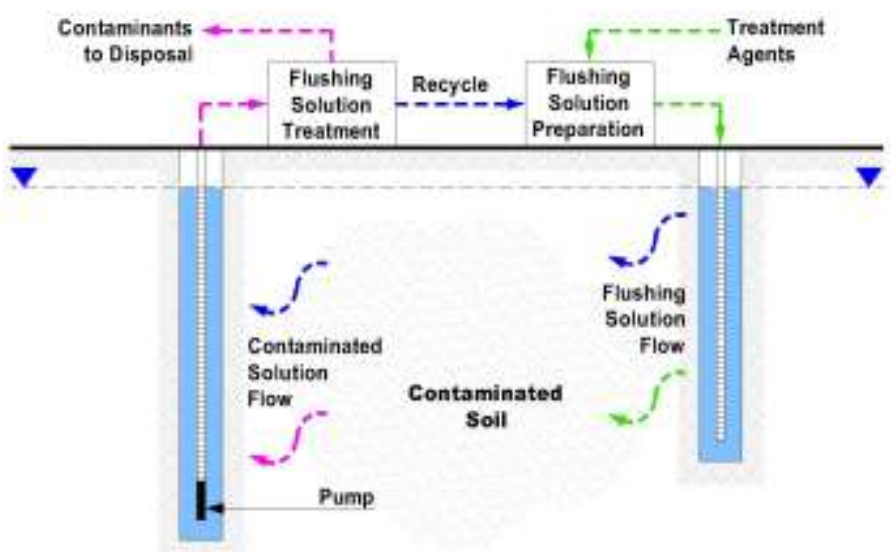

Fig. 3. Soil flushing technology, potentially possible for Inčukalns contamination plume treatment.

\section{CONCLUSIONS}

In Latvia, the assessment and evaluation of contaminated and potentially contaminated sites began in the 1980s. The National Register of Contaminated Territories (NRCT) covers the territories that are contaminated with various materials, inorganic and organic, including hazardous and nonhazardous substances. NRCT divides the sites in three categories: the first includes 242 contaminated sites (contamination exceeds the acceptable normative 10 times or more); the second - 2655 sites, and the third - 669 contaminated areas. The latter mostly comprises the territories excluded from the lists of the first and second categories after the conducted research and/or remediation activities.

The following contaminated site division can be proposed former dump sites of mixed waste, former military territories, industrial brownfields, especially liquid and semi-liquid hazardous sites, and contaminated areas in general. Mostly contamination with heavy metals and oil products was observed.

At present, stabilization/solidification, soil flushing, electrokinetic treatment, phytoremediation, and bioremediation are applied in Latvia.

The opportunity to collaborate within the EU remediation framework of historically contaminated territories gives one a chance to carry out environmental research and follow-up with remediation projects in problematic areas. In 2010 the promotion of two large-scale stabilization/solidification (S/S) projects began for the territories in Liepaja and Riga ports. These projects should be viewed as pilots for further development of remediation works in Latvia. The use of the S/S technology is not the only solution for the remediation and demobilisation of toxic agents; further research might be done to draw a sketch for the use of other heavy metal remediation technologies, such as electrokinetics, phytoremediation, bioremediation, separation/concentration and others, regarding the type of contamination, the size of the problem and the specifications of the investigated areas. The Inčukalns project is even more complex, because the soil treatment has to be done mostly using groundwater treatment technologies.

\section{REFERENCES}

1. Bolenz, S., Omran, H., Gierschner, K. Treatments of Water Hyacinth Tissue to Obtain Useful Products. Biol. Wastes, 1990, 22, p. 263-274.

2. Conway R.A., Cordle S., Mercer J.W., Miller D.W., Rao P.S.C. Overview. In: Ground Water and Soil Contamination Remediation: Toward Compatible Science, Policy, and Public Perception. Report on Colloquium Sponsored by the Water Science and Technology Board. Colloquium 5 of a Series, National Academy Press, Washington, D.C., 1990, p. 1-16.

3. Emerging Technologies for the Remediation of Metals in Soils. Electrokinetics. Technology Overview. Interstate Technology and Regulatory Cooperation Work Group. December, 1997, 19 p.

4. Gailius, A., Vacenovska, B, Drochytka, R. Hazardous Wastes Recycling by Solidification / Stabilization Method. Materials Science. 2010, Vol. 16, No.2. p. 165-169.

5. Gonzaga, M.I.S., Santos, J.A.G., Ma, L.Q. Arsenic Phytoextraction and Hyperaccumulation by Fern Species. Sci.Agric. (Piracibaba, Brazil), 2006, v.63, n.1, p. 90-101.

6. Glick, B.R. Phytoremediation: Synergetic Use of Plants and Bacteria to Clean Up the Environment. Biotechnology Advances, 21, 2003, p. 383393.

7. Informative Report. On Legislative Regulations for Remediation of Contaminated Sites with Historical Military Unexploded Ammunition and Explosive Objects. The Ministry of Environment. October, 2006.

8. Kafka, Z., Puncocharova, J. Binders and Additives for Chemical Stabilization of Hazardous Wastes. Journal of Chemical Letters 96. Institute of Chemical Technology, Prague, Department of Environmental Chemistry, 2002.

9. Kosson, D.S., van der Sloot, H.A., Sanchez, F., Garrabrants, A.C. An Integrated Framework for Evaluating Leaching in Waste Management and Utilization. Engineering Science 19, 2002.

10. 15.03.2001. Law "On Pollution" (Par piesārņojumu) ("LV", 51 (2438), 29.03.2001.; Ziņotājs, 9, 03.05.2001.) [in power from 01.07.2001.]; with Amendments.

11. Lombi, E., Wenzel, W.W., Adriano, D.C. Soil Contamination, Risk Reduction and Remediation. Land Contamination \& Reclamation, 1998, 6 (4), p. 183-197.

12. Malviya, R., Chaudhary, R. Factors Affecting Hazardous Wastes Solidification / Stabilization: A Review. Journal of Hazardous Material, 2006, 137 (1) p. 267-276.

13. Mulligan, C.N., Yong, R.N., Gibbs, B.F. Remediation Technologies for Metal-contaminated Soils and Groundwater: An Evaluation. Engineering Geology, 2001, 60, p. 193-207.

14. Müller G. Schwermetalle in den Sedimenten des Rheins-Vera Ènderungen seit. Umschau, 1979, 79 (24), p. 778-783.

15. Prokop G., Schamann M., Edelgaard I. Management of contaminated sites in Western Europe. Topic Report, 1999, No 13. European Environment Agency, Copenhagen.

16. Reddy, K.R., Adams, J.F., Richardson, C. Potential technologies for remediation of Brownfield. Practice Periodical of Hazardous, Toxic, and Radioactive Waste Management, 1999, 3(2), p. 61-68.

17. 20.11.2001. Regulation of the Cabinet of Ministers Nr.483. Identification and Registration of Contaminated and Potentially Contaminated Sites (Piesārṇoto un potenciāli piesārṇoto vietu apzināšanas un reǵistrācijas 
kārtība) ("LV", 171 (2558), 27.11.2001.) [in power from 28.11.2001.]; with Amendments.

18. Roehl K.E., Gregolec G. Implementation of Remediation Technologies Theory and Practice. Land Contamination \&Reclamation, 2005, 13 (2), p. 123-136.

19. Sarma H. Metal Hyperaccumulation in Plants: A Review Focusing on Phytoremediation Technology. Environmental Science and Technology, 2011, 4 (2) p. 118-138.

20. Sas-Nowosielska A, Galimska-Stypa R, Kucharski R, Zielonka U, Malkowski E, Gray L. Remediation aspect of microbial changes of plant rhizosphere in mercury contaminated soil. Environ Monit Assess. Feb. 2008, 137 (1-3).

21. Tomlinson, D. L. Wilson, J. G. Harris C. R. and Jeffrey, D. W. Problems in the assessment of heavy-metal levels in estuaries and the formation of a pollution index. Helgoland Marine Research, 1980, Volume 33, Numbers 1-4, p. $566-575$.

22. Vanheusden, B. Recent Development in European Policy Regarding Brownfield Remediation. Environmental Practice, 2009, 11 (4), p. 256262.

23. Vircavs M. Sediment Quality Assessment in Latvia Water Bodies. Ecological Chemistry and Engineering, 2008, Vol. 15. No 8. p. 831-839.

24. Kafka Z., Vosicky, J. Chemical Stabilization of Hazardous Components in Industrial Wastes. Conference Proceedings Symposium Waste Disposal and Treatment, 1999, Czech Republic.

25. Wilk C. M. Solidification/Stabilization Treatment and Examples of Use at Port Facilities. Ports 2004: Port Development in the Changing World. ASCE Conference Proceedings, 2004, $10 \mathrm{p}$

26. 9VAC20-160-10. Definitions. Virginia Register Volume 13, Issue 18, eff June 26, 1997; amended, Virginia Register Volume 18, Issue 18, eff. July 1, 2002. Accessed: 01.04.2011. Available: http://leg1.state.va.us/cgibin/legp504.exe?000+reg+9VAC20-160-10

27. National Register of Contaminated and Potentially Contaminated Sites (Piesārņoto un potenciāli piesārņoto vietu registrs). LVG̣MC. Accessed: 07.04.2011. Available: http://oas.vdc.lv:7779/p_ppv.html

28. Liepaja Navy Port Environmental Research (Liepajas ostas vides izpēte). ES PHARE programme and the Government of Latvia. Report: Baltec Associates, Inc, 1996.

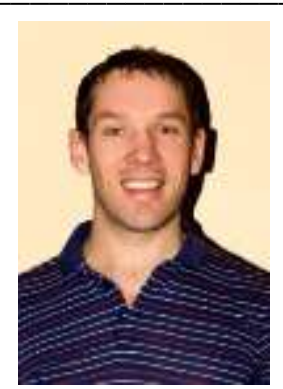

Juris Burlakovs is the doctoral student of Environmental Sciences at the University of Latvia. Particularly the scientific interest is focused on heavy metal contamination remediation technologies and applications of those in different geoecological conditions. Previously he has gained Master degrees in Environmental Management (2009) and Quaternary Geology and Geomorhology (2002) at the University of Latvia, has shortly studied environmental engineering at the University of Padova, Italy.

He works at Environmental Consultancy Bureau Ltd. in Riga as the Environmental Specialist, also has the private practice of drilling works for water supply issues. Earlier career is bound with geomagnetic research and geology.

$\mathrm{He}$ is the member of Latvian Association for Quaternary Research and Latvian Astronomical Society.

Address: Alberta Str. 10, LV-1014, Riga, Latvia

Phone: +371 28469044

E-mail: jurisb@vkb.lv

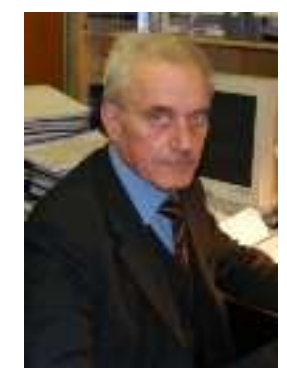

Magnuss Vircavs, Dr.hab.chem., assoc. professor, Faculty of Geography and Earth Sciences, University of Latvia. Assoc. professor Magnuss Vircavs has been part of academic staff of the Faculty of Geography and Earth Sciences, University of Latvia since 2000. The main research areas are trace element pre-concentration, determination, and distribution studies in water ecosystems as well as in environmental management mainly in the sphere of environmental impact assessment. He has participated in different local and international projects related to environmental assessment and is author (and co-author) of more than 60 publications and 6 books. M. Vircavs has two-step doctoral degree diploma. Diploma $\mathrm{PhD}$ thesis "Concentration of Heavy Metal Traces by Coprecipitation with Bis(8-Quinolyl) Disulphide and its Derivatives" was defended in the Institute of Inorganic Chemistry, Latvian Academy of Sciences, Riga (1980). Doctor Habilitus Thesis "Study of Trace Element Coprecipitation with Organic Disulphides" was defended in Technical University of Gdansk, Poland (1998).

\section{Juris Burlakovs, Magnuss Vircavs. Grunts sanācijas tehnoloǵijas un pielietojuma iespējas Latvijā}

Vides piesārṇojumam un tā ietekmei uz cilvēka veselību mūsdienās ir aizvien lielāka nozīme, tādēl arī Latvijas Republikā ir izveidota normatīvā bāze piesānnojošo vielu emisiju vidē samazināšanai, taču joprojām pastāv liels skaits teritoriju, kurās konstatēts augsts vēsturiskā piesārņojuma līmenis. Rakstā sniegts Latvijas piesārņoto vietu apskats, kā arī doti ieteikumi sanācijas darbu veikšanai šajās teritorijās. Latvijā ir 242 piesārņotās vietas atbilstoši 1 . kategorijai (piesārnojuma līmenis pārsniedz pielaujamās robežvērtības 10 un vairāk reizes), kas ieklautas Piesārnoto un potenciāli piesārnoto vietu reǵistrā. Daudzas no šīm teritorijām ir stipri piesārṇotas ar bīstamām vielām - smagajiem metāliem, naftas produktiem, organiskajiem savienojumiem, kā arī citām piesārṇojošām vielām un elementiem. Pirms atbilstošu metožu izvēles ir jāveic pētījumi, kas ietvertu esošas rūpnieciskās vai bijušās militārās teritorijas vides pirmsizpēti piesārṇojuma veida, daudzuma un koncentrācijas noteikšanai, lai varētu izvērtēt sanācijas darbu nepieciešamību un izvēlēties piemērotāko un efektīvāko tehnoloǵiju. Pētījumu rezultātā, izvērtējot situāciju, tiek izvēlēta zinātniski un ekonomiski pamatota tehnoloǵija jeb to komplekss, kas ḷautu veikt efektīvus sanācijas darbus. Visbiežāk grunts un gruntsūdens piesārnojums ir jāvērtē kompleksi. Rakstā ir apskatîti dažādi potenciālie sanācijas tehnoloǵiskie risinājumi, kas būtu pielietojami Latvijā, kā arī dotas rekomendācijas konkrētu tehnolog̣iju izmantošanai noteiktās teritorijās ar nozīmīgāko vēsturiskā piesārṇojuma līmeni.

\section{Юрис Бурлаковс, Магнус Вирцавс. Возможное использование технологий очистки загрязненных грунтов Латвии}

Загрязнение окружающей среды и его влияние на здоровье человека сегодня имеет все большее значение, поэтому в Латвии разработана нормативноправовая база для уменьшения выбросов загрязняющих веществ в окружающую среду, но все-таки до сих пор имеется большое количество мест с высоким уровнем исторического загрязнения. Статья содержит обзор загрязненных участков Латвии, а также дает рекомендации для проведения очистных работ в этих местах. В Латвии имеются 242 загрязненные территории первой категории (уровень загрязнения превышает допустимые нормы в 10 и более раз), которые входят в Регистр загрязненных и потенциально загрязненных мест. Многие из них значительно загрязнены опасными веществами - тяжелыми металлами, нефтепродуктами, органическими соединениями, а также другими веществами. Перед выбором соответствующих технологий очистки должны провестись исследования, которые включают технически-экономическое обоснование ведения работ и заключение об объемах и концентрациях загрязняющих веществ. Это позволяет обеспечить эффективные результаты в проектах очистки загрязненных грунтов и грунтовых вод, что должно рассматриваться комплексно. В статье рассматриваются различные технологические решения, которые были бы применимы в очистке загрязненных территорий Латвии, а также даются рекомендации по использованию определенных технологий в участках с наиболее значительным уровнем исторического загрязнения. 